\title{
Contaminação de frascos de colírios de soro autólogo
}

\author{
Autologous serum eyedropper contamination after topical use
}

\author{
Ana Luisa Höfling'-Lima ${ }^{(1)}$ \\ Acácio Souza Lima ${ }^{(2)}$ \\ José Antonio Batistoso ${ }^{(3)}$ \\ Débora Kawamura ${ }^{(4)}$ \\ Maria Regina Catai Chalita ${ }^{(5)}$ \\ Leandro Siqueira Alves ${ }^{(5)}$ \\ Michel Eid Farah ${ }^{(6)}$
}

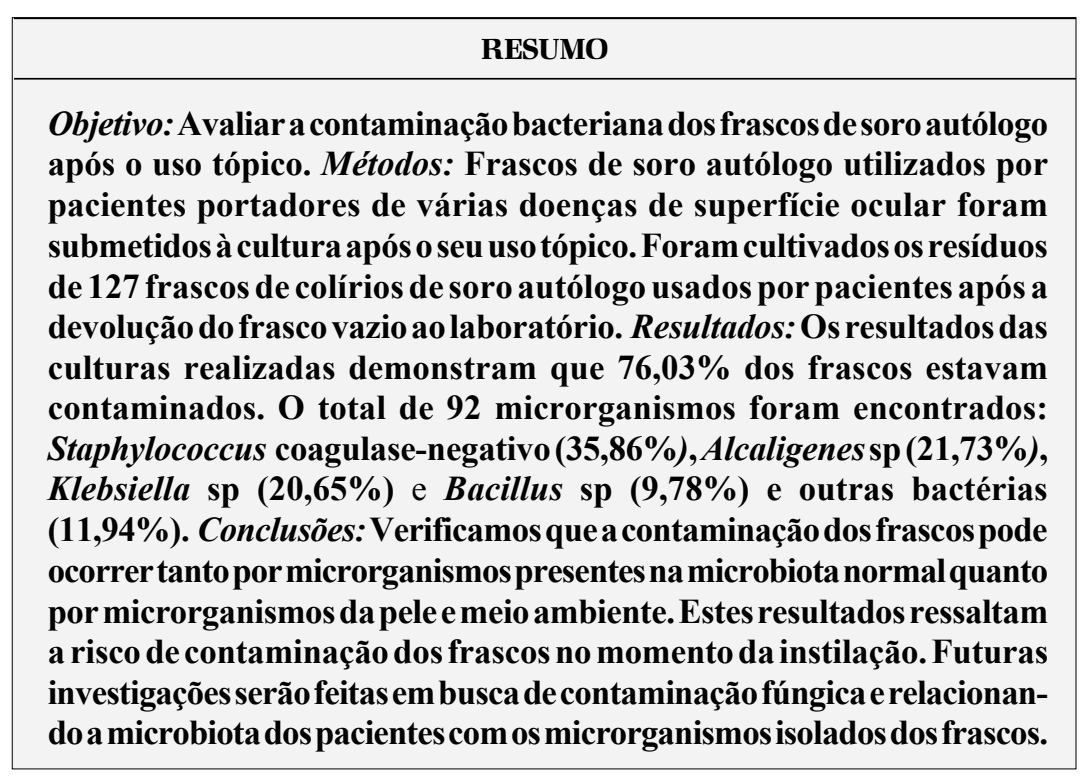

Descritores: Soluções oftálmicas/análise; Contaminação de medicamentos; Infecções bacterianas do olho; Staphylococcus; Alcalígenes; Klebsiella.
(1) Prof. Adjunto e Chefe do laboratório de Microbiologia do Departamento de Oftalmologia da UNIFESP/EPM

(2) Farmacêutico - Pós-graduando nível doutorado do Departamento de Oftalmologia da UNIFESP/EPM 3) Farmacêutico - Chefe do Laboratório Oftalmolab. Bióloga do Laboratório Oftalmolab.

(5) Oftalmologista - Pós-graduando(a) nível doutorado do Departamento de Oftalmologia da UNIFESP/EPM.

(6) Livre-Docente do Departamento de Oftalmologia da UNIFESP/EPM.

Endereço para correspondência: Ana Luisa HöflingLima - Av. Ibijaú, 331 - $4^{\circ}$ andar. São Paulo (SP) CEP 04524-020. E-mail: coftalmo@uol.com.br

\section{INTRODUÇÃO}

$\mathrm{Na}$ literatura oftalmológica encontramos casos descritos de infecções oculares bacterianas transmitidas por colírios contaminados ${ }^{1,2}$. A manutenção da esterilização dos medicamentos usados topicamente é importante visto que em muitas situações pode haver uma modificação da defesa natural do próprio paciente ${ }^{3,4}$.

O colírio de sangue autólogo é utilizado para o tratamento de doenças como a ceratoconjuntivite sicca ${ }^{5-8}$, e em geral pacientes que fazem uso deste tipo de medicação possuem alterações de superfície ocular, o que pode predispor a possíveis infecções oculares ${ }^{7-8}$.

Outros estudos que analisaram a contaminação de colírios anestésicos associados ou não ao corante vital fluoresceína ${ }^{4}$, ou colírios de uso geral ${ }^{3,9}$, verificaram que existe a possibilidade de contaminação tanto por microorganismos Gram positivos como por microrganismos Gram negativos.

Este estudo tem como objetivo avaliar a contaminação de resíduos em frascos de colírios de soro autólogo após o uso tópico.

\section{MÉTODOS}

Foram avaliados os resíduos de 127 frascos de colírios de sangue autólogo $100 \%$ manipulados pelo laboratório Oftalmolab no período de Dezembro de 1998 a Abril de 2000. 
O colírio de sangue autólogo foi preparado a partir do sangue do próprio paciente, não possuindo preservantes e sendo conservado sob refrigeração $\left(-4^{\circ} \mathrm{C}\right)$. Coletou-se 20 mililitros de sangue venoso do paciente, que permaneceu em temperatura ambiente até coagular (aproximadamente 40 minutos). O material foi centrifugado a $5000 \mathrm{rpm}$ por 10 minutos, havendo deste modo a separação do soro que foi colocado em frascos esterilizados com raio gama, segundo todos os critérios de assepsia exigidos.

Para controle do medicamento, após todo o processamento do colírio, pingou-se uma gota do soro de cada frasco numa placa de Ágar sangue e incubou-se a $37^{\circ} \mathrm{C}$ por 18 a 24 horas. Após verificação de que não houve crescimento bacteriano na placa de Ágar sangue, o colírio foi entregue ao paciente.

Juntamente com o colírio, cada paciente recebeu uma carta com orientações sobre como aplicar o colírio e evitar a contaminação pelo uso, bem como a recomendação de guardálo sob refrigeração. Ao final de cada frasco o paciente era orientado a devolver os frascos vazios para identificação de eventuais contaminações pelo uso. Esta devolução do frasco fechado mantido em temperatura ambiente ocorre até uma semana após o término do uso.

No laboratório, o material residual dos frascos devolvidos foi analisado com cultura e identificação de microrganismos. Foi colhido material residual dos frascos abrindo-se os mesmos em câmara com fluxo laminar com uma zaragatoa estéril e alginatada. Todas as amostras colhidas para cultura foram semeadas em meio sólido (Ágar sangue). Considerou-se cultura positiva quando houve o crescimento de microrganismos consistente em pelo menos duas estrias em cada amostra.

\section{RESULTADOS}

Dos 127 frascos de colírios de soro autólogo estudados, 42 (33,07\%) mantiveram-se estéreis até a devolução e após a finalização do uso tópico. Um total de 79 frascos estavam contaminados por apenas 1 microrganismo, 5 frascos apresentavam contaminação por 2 microrganismos distintos e 1 frasco apresentava contaminação por 3 microrganismos distintos com um total de 85 frascos contaminados e 92 microorganismos identificados.

$\mathrm{Na}$ análise dos 92 microrganismos encontrados observou-se maior freqüência de bactérias Gram positivas, sendo o microrganismo mais comum o Staphylococcus coagulase-negativo (33 - 35,86\%), seguido por outras bactérias Gram negativas, como Alcaligenes sp (20 - 21,73\%) e Klebsiella sp (19 - 20,65\%). Em menor freqüência foram encontrados Bacillus sp (9 - 9,78\%), Escherichia coli (4 - 4,34\%), Proteus sp (3 - 3,26\%), Staphylococcus aureus (3 - 3,26\%) e Enterobacter sp (1 - 1,08\%).

\section{DISCUSSÃO}

Apesar das indústrias farmacêuticas procederem rotineiramente as provas de esterilidade em seus medicamentos, vários fatores interferem na manutenção e perpetuação desta esterilidade após a abertura do frasco. Podemos citar como fatores importantes: as condições ambientais e a forma de manipulação do colírio, evitando o contato de qualquer parte do frasco com o olho ou pele do paciente.

Os microrganismos usualmente presentes na microbiota normal Staphylococcus coagulase-negativo foram responsáveis pela maior parte de culturas positivas dos frascos de soro autólogo. Microrganismos que não fazem parte da microbiota normal também foram isolados como contaminantes. O microrganismo mais comum da flora normal foi o Staphylococcus epidermidis $(35,86 \%)$, seguido de Klebsiella $\mathrm{sp}$ (20,65\%) e Proteus sp (3,26\%).

Como o microrganismo mais freqüentemente encontrado nos frascos contaminados foi o Staphylococcus coagulasenegativo, que faz parte da flora ocular normal, podemos deduzir que os colírios podem ser contaminados com microorganismos presentes na margem palpebral e conjuntiva por contato direto no momento de instilação ${ }^{9}$. O índice de contaminação de $21,2 \%$ observado em estudo que analisa as medicações durante o uso mesmo contendo preservantes nos encoraja a investigar a possível contaminação do soro autólogo enquanto está em uso e não apenas do resíduo do frasco ${ }^{8-9}$.

Embora nenhum paciente usando o soro autólogo tenha apresentado infecção ocular durante a utilização destes, constatamos que o resíduo de vários frascos apresentava contaminação após o uso. Apesar do risco, não é possível afirmar que este tipo de contaminação verificada nos resíduos dos frascos seja um fator predisponente às infecções oculares.

Outro fator importante a ser considerado foi o fato dos pacientes guardarem os frascos fechados a serem devolvidos ao laboratório após o uso tendo ficado em temperatura ambiente por uma semana. Este intervalo em ambiente não refrigerado poderia modificar o crescimento de microrganismos provavelmente já inoculados no vidro.

Futuras investigações serão feitas no sentido de relacionar a esterilidade e a contaminação dos frascos com os pacientes, verificando seus hábitos e sua microbiota bacteriana. A avaliação da contaminação fúngica e a avaliação da possibilidade do soro autólogo ser um bom substrato para o crescimento de bactérias e fungos in vitro será o objetivo de pesquisas futuras do nosso grupo.

\section{CONCLUSÕES}

Verificamos que a contaminação dos frascos pode ocorrer tanto por microrganismos presentes na microbiota normal quanto por microrganismos da pele e meio ambiente. Estes resultados ressaltam risco de contaminação dos frascos no momento da instilação. Futuras investigações serão feitas em busca de contaminação fúngica e relacionando a microbiota dos pacientes com os microrganismos isolados dos frascos. 


\section{ABSTRACT}

Purpose: To evaluate bacterial contamination of autologous serum eyedroppers after topical use. Methods: Autologous serum eyedroppers used for ocular surface diseases were submitted to culture after topical use. A total of 127 eyedroppers was cultivated after the patients had used the drops and returned them to the laboratory. Results: We found that $76.03 \%$ of the eyedroppers were contaminated. Nine-two microorganisms were found: coagulase-negative Staphy-lococcus (35.86\%), Alcaligenes sp (21.73\%), Klebsiella $s p(20.65 \%)$ and Bacillus $s p(9.78 \%)$. Conclusion: The eye-dropper contamination can be caused by normal flora and by skin and environmental microor-ganisms. These results show the contamination risk at the moment of instillation. Further research will be done to evaluate fungal conta-mination and to correlate the patient's normal flora with microorganisms found in the eyedroppers.

Keywords: Ophthalmic solutions/analysis; Drug contamination; Bacterial eye infections; Staphylococcus; Alcaligenes; Klebsiella.

\section{REFERÊNCIAS}

1. Templeton III WC, Eiferman RA, Snyder JW, Melo JC, Raff MJ. Serratia keratitis transmitted by contaminated eyedroppers. Am J Ophthalmol 1982;93:723-6.

2. Alfonso E, Kenyon KR, Ormeron LD, Stevens R, Wagoner M, Albert DM. Pseudomonas corneoscleritis. Am J Ophthalmol 1987;103:90-8.

3. Roizenblat J, Inomata S. Contaminação de colírios. Rev Bras Oftalmol 1982;41:55-9.

4. Kawagakami LT, Prata Jr JA, Reys JC, Guidugli T, Mello PAA. Avaliação da contaminação bacteriana na mistura de colírios de fluoresceína e drogas anestésicas. Arq Bras Oftalmol 1995;58:186-8.

5. Fox RI, Chan R, Michelson JB, Belmont JB, Michelson PE. Beneficial effect of artificial tears made with autologous serum in patients with keratoconjunctivitis sicca. Arthritis Rheum 1984;27:459-61.

6. Tsubota K, Goto E, Fujita H, Ono M, Inoue H, Sito I, Shimmura S Treatment of dry eye by autologous serum application in Sjogren's syndrome. Br J Ophthalmol 1999;83:390-5.

7. Tsubota K, Goto E, Shimmura S, Shimazaki J. Treatment of persistent corneal epithelial defect by autologous serum application. Ophthalmology 1999;106:1984-9.

8. Tsubota K, Satake Y, Ohyama M, Toda I, Takano Y, Ono M, Shinozaki N, Shimazaki J. Surgical reconstruction of the ocular surface in advanced ocular cicatricial pemphigoid and Stevens-Jonhson Syndrome. Am J Ophthalmol 1996;122:38-52

9. Pereira IC, Alfonso E, Souza MACM, Song D, Muller D. Avaliação da contaminação de produtos oftálmicos em uso. Arq Bras Oftalmol 1992;55:15-8.

\title{
VIII SIMPÓSIO INTERNACIONAL DE CATARATA E LENTE INTRA-OCULAR
}

\author{
16 e 17 de Março de 2.001
}

\author{
Gran Meliá Hotel - São Paulo - SP
}

\section{Promoção: Seminário Oftalmológico da UNICAMP}

\author{
Informações: JDE Comunicação e Eventos \\ Tels.: (0xx11) 289-4301 / 287-9699/ 287-9378 \\ Fax: (0xx11) 288-8157 \\ e-mail: jdecomev@uol.com.br
}

